\section{Quantitative Enzyme Profiles of Plaques of Multiple Sclerosis ${ }^{1}$}

Histochemical studies of enzymes in brain tissue from human beings with multiple sclerosis have shown abnormally high activity at the margin of demyelinated plaques and low activity within the plaques. This has been reported for cytochrome oxidase ${ }^{2}$, DPN-diaphorase and succinic dehydrogenase ${ }^{3}$, lactic dehydrogenase and ATPase, and acid phosphatase 8 . The present study reports quantitative measurements of lactic dehydrogenase (LDH) and DPN-diaphorase activity in the plaques of multiple sclerosis, the margin of the plaques, and the adjacent myelinated white matter.

Human post mortem brain tissue from a 45-year-old female was obtained less than $6 \mathrm{~h}$ after death. Methodology for handling the tissue, the procedure for quantitative measurements, and the modification of the SCARPelli, Hess, and Pearse method ${ }^{\circ}$ used for DPN-diaphorase have been described previously?. The method of ALLEN and SLATER ${ }^{8}$ was used for LDH. For DPN-diaphorase and LDH, sections used for microscopic study were incubated in a medium containing nitro blue tetrazolium, and sections used for quantitative measurements were incubated in a medium containing iodonitrotetrazolium. Every 9th section through a tissue block was stained with Sudan black in propylene glycolol and some of the sections previously incubated for microscopic enzyme studies were counterstained with Fettrot $7 \mathrm{~B}$. For quantitative measurements of the enzyme reactions, discs of tissue $2.4 \mathrm{~mm}$ in diameter were punched from $30 \mu$ sections that had been incubated for DPN-diaphorase and LDH activity. To obtain a profile of enzyme activity, a continuous series of discs were punched on an imaginary line in the myelinated white matter, the peripheral zone of the plaque, and the plaque itself. For each plaque studied, ten $\mathrm{LDH}$ and ten DPN-diaphorase profiles were made. A total of 1423 measurements was obtained. The peripheral zone of the plaques was usually less than 1.5 $\mathrm{mm}$ wide, so the $2.4 \mathrm{~mm}$ disc from it was contaminated with tissue from both sides. To more precisely determine the activity in the peripheral zone, three discs, $1.1 \mathrm{~mm}$ in diameter, were taken and their measured value extrapolated to that of a $2.4 \mathrm{~mm}$ disc. The extrapolated values were used in the profiles.

The distribution of $\mathrm{LDH}$ and DPN-diaphorase activity in this study was similar (Figures 1 and 2). In agreement with densitometric measurements of DPN-diaphorase activity of a previously studied case of multiple sclerosis ${ }^{3}$, the enzyme activity in tissue outside the plaques was relatively normal, in the peripheral zone of the plaques it was abnormally high, and inside of the plaques it was abnormally low. In comparison with the myelinated tissue outside of the plaques, there was an average of $28 \%$ increase of enzyme activity in the peripheral zones and a $64 \%$ decrease of activity inside the plaques. The extent of increase of enzyme activity in the peripheral zone varied considerably among plaques and probably reflected the age of the plaque and acuity of the demyelinating process, as implied by previous studies ${ }^{8}$ which showed that there was no increase of DPN-diaphorase activity at the periphery

1 This research was supported by U.S. Public Health Grant B-3250.

L. Rouzin, J. Neuropath. exp. Neurol. 8, 381 (1949)

3 R. L. Friede, A.M.A. Arch. Neurol. 5,433 (1961).

-M. Z. M. I iratim and C. W. M. Adams, J. Neurol, Neurosurg. Psychiat. 2e, 101 (1963)

BH. Landow, E. A. Kabat, and W. Newman, A.M.A. Arch. Neurol. 48, 518 (1942).

- D. G. Scarpelli, R. Hess, and A. G. E. Pearse, J. Biophys. Biochem. Cytol. 4, 747 (1958).

'R. L. Friede, L. M. Fleming, and M. Knoller, J. Histochem. Cytochem. 11, 232 (1963).

8 J. M. Alles and J. J. Stater, J. Histochem. Cytochem. 9, 221 (1961).

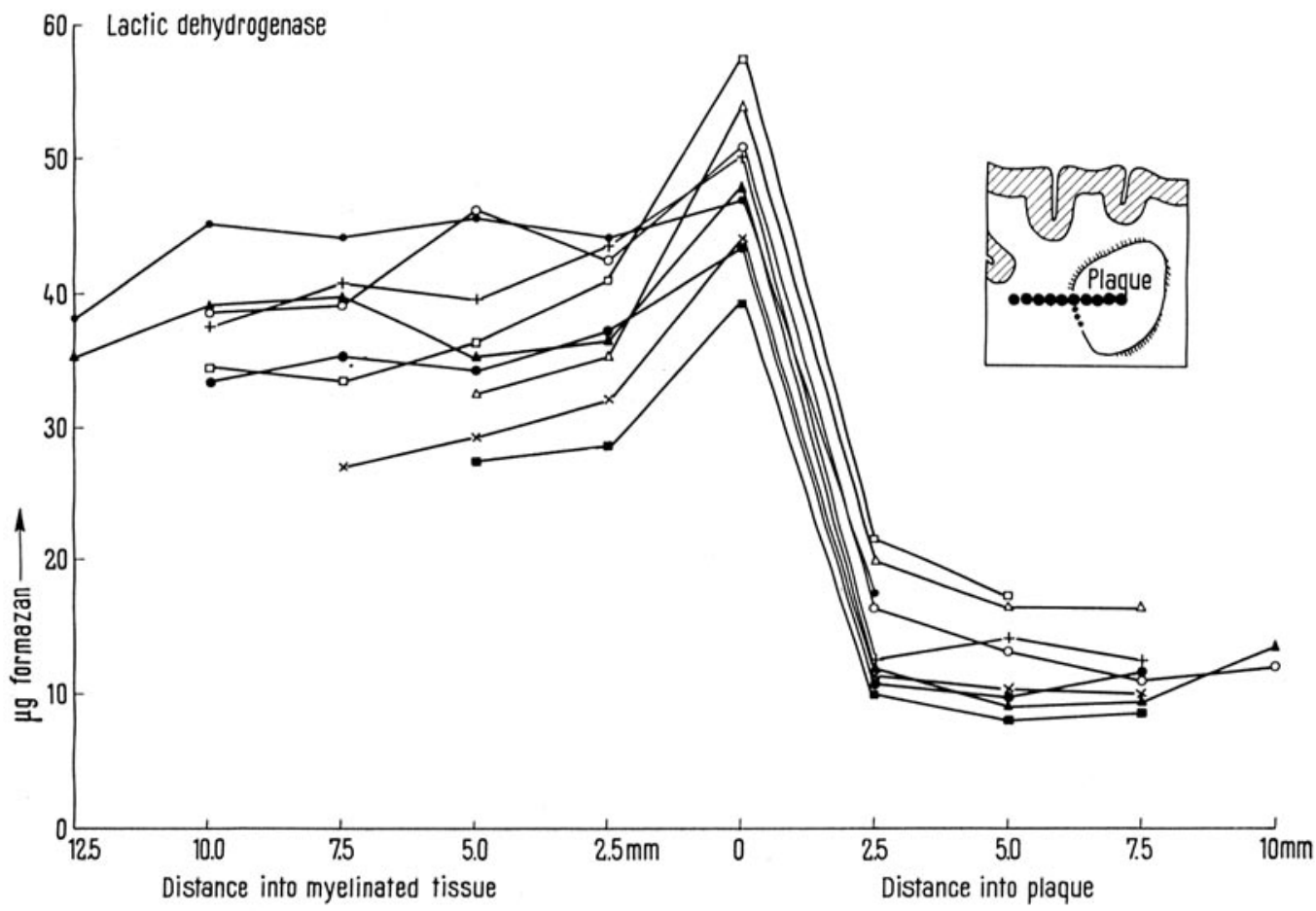

Fig. 1. Changes of lactic dehydrogenase in nine demyelinated plaques: each curve represents one plaque, each point in the curve represents an average of 10 measurements. The drawing illustrates the way in which the individual samples were taken. 


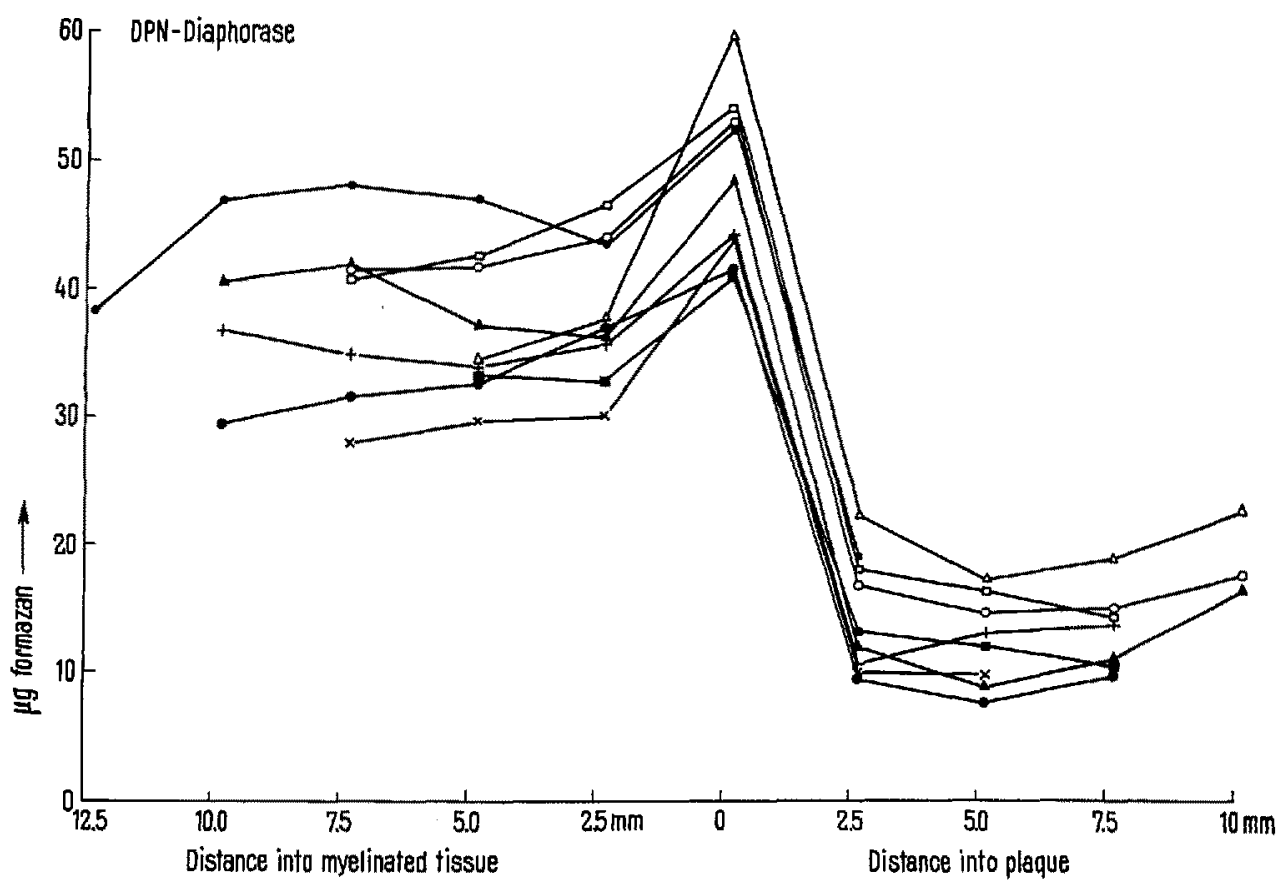

Fig. 2. Measurements of DPNdiaphorase in the same material as shown in Figure 1. of stationary plaques. In the present study, young plaques that were only 2.5 to $3 \mathrm{~mm}$ in diameter were microscopically observed to have extremely high enzyme activity in their peripheral zones and relatively little loss of activity inside the zone; this indicated that demyelination was completed prior to the loss of enzyme activity. Fettrot $7 \mathrm{~B}$ counterstained sections of plaques of all sizes showed that the outer part of the peripheral zones with increased enzyme activity was myelinated tissue but the inner part was demyelinated like the rest of the plaque.

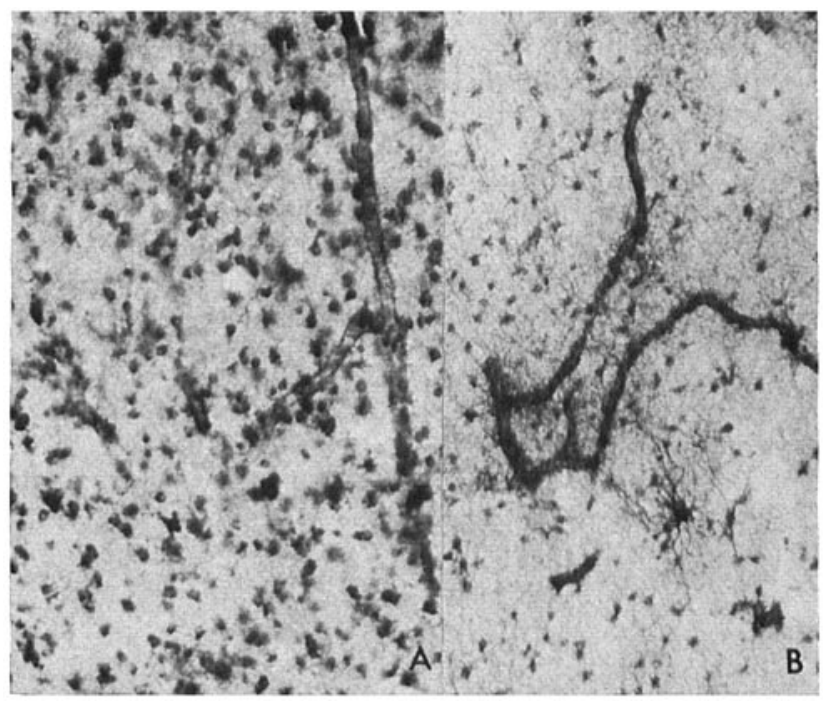

Fig. 3. Distribution of lactic dehydrogenase in myelinated white matter outside of the plaque (A) and within the plaque (B). These pictures illustrate the cytological distribution of the enzyme activity measured in the extreme left and right portions of the curves in Figure 1.
Microscopic studies of normal white matter of human cerebral hemispheres ${ }^{9}$ showed that most of the oxidative enzyme activity was localized in oligodendroglia; minor fractions of the total activity were in the blood vessels and in axons. The present data on LDH and DPNdiaphorase evidence some scatter of the measurements of enzyme activity in the white matter adjacent to the individual plaques. This reflected partly, that the plaques were obtained from various regions of white matter; partly, it reflected superposed pathological changes. Cytologically, the myelinated white matter in the vicinity of the plaques looked normal (Figure 3A) except for the variable numbers of reactive astrocytes. The enzyme reaction was much more intense in reactive astrocytes than in oligodendroglia. In the peripheral zone of the plaques, increased activity was localized in numerous hypertrophic astrocytes; there was also a marked reaction, diffusely distributed between these cells. Inside of the plaque, the loss of enzyme activity was correlated with a significant decrease in cell population; the remaining enzyme activity was in blood-vessel walls, and in scattered hypertrophic astrocytes (Figure 3B). The rest of the cell population had less enzyme activity than oligodendroglia normally have and was thought to be microglia or possibly non-reactive astrocytes. FRIEDE ${ }^{3}$ and IBRAHIM and ADAMS both reported a marked decrease of the total number of glia cells in the plaque, but IBRAFIM and ADAMs identified the remaining cells as oligodendroglia, whereas we could not distinguish oligodendroglia in the plaques where enzyme activity was decreased. The interpretation that most, if not all, oligodendroglia cells have disappeared from the demyelinated tissue ${ }^{3,10}$ is in keeping with the $64 \%$ loss of enzyme.

I R. L. FrIEDE, J, Neurochem. 8,17 (1961).

${ }^{10}$ C. E. Lumsden, Brit. Med. J. 1951, 1035. 
Zusammenfassung. Quantitative histochemische Methoden für Milchsäuredehydrogenase und DPN-Diaphorase wurden zum Studium von Plaques von multipler Sklerose in menschlichem post-mortem-Material angewendet. Im Vergleich mit myelinisierter weisser Substanz zeigten die Plaques eine um $28 \%$ vermehrte Fermentaktivität in der Randzone und eine Abnahme von $64 \%$ innerhalb des demyelinisierten Gewebes, was mit Veränderungen der intrazellulären Fermentverteilung in Beziehung gebracht werden kann.

\section{R. L. FRTEDE and M. KNOLLER}

Mental Health Research Institute and Department of Pathology, The University of Michigan, Ann Arbor (U.S.A.), December 23, 1963.

\section{Inhibition of Respiration of Aspergillus oryzae by Adsorption of the Mycelium on Cellulose Acetate Fibres}

During a study of the respiration of Aspergillus oryzae, when the mycelium was freed from its substrate by a finemesh filter of nylon or cellulose acetate, occasional small irregularities suggested that the filter might interfere with the respiration activity. The experiments reported here were designed to determine whether adsorption of the mycelium on cellulose acetate could have such an influence.

The mould was grown in substrate $A_{4}$ at $25^{\circ} \mathrm{C}$ in deep culture with forced aeration and agitation 1,2 ; the size of inoculum was $2 \times 10^{7}$ washed conidia/100 ml substrate; homogenous filamentous growth was obtained. After $23.5 \mathrm{~h}$ when the content of mycelium was $4.9 \mathrm{mg}$ dry weight $/ 100 \mathrm{ml}$, the respiration activity (rate of $\mathrm{O}_{2}$ uptake determined at $25^{\circ} \mathrm{C}$ by the direct method of Warburg) of the mycelium was tested under a variety of conditions as shown in the Table. Linear reaction curves were obtained over the test periods of 2.5 to $3 \mathrm{~h}$. In the following an untreated filter refers to cellulose acetate fabric which has been used many times for the recovery of mycelium and which has been rinsed in tap water and distilled water. A detergent-treated filter is the same fabric treated with detergent ('Pyroneg' - Deosan Ltd., London) then rinsed thoroughly in hot and cold tap water and cold distilled water.

When the culture was examined without treatment i.e. the mycelium not freed from its substrate and with no change in concentration of mycelium, or when $50 \mathrm{ml}$ of the culture were filtered through an 'untreated' filter of cellulose acetate fabric followed by suspending the mycelium quantitatively in $5 \mathrm{ml}$ of its culture filtrate, the specific rate of respiration $\left(\mathrm{QO}_{2}\right)$ in several tests over 2.3 to $3 \mathrm{~h}$ was between 158 and $184 \mu \mathrm{l} \mathrm{O}_{2}$ per $\mathrm{mg}$ dry weight

Specific rate of respiration $\left(\mu 1 \mathrm{O}_{2} / \mathrm{mg}\right.$ h) of unwashed mycelium and of mycelium washed on a strongly adsorbing (detergent-treated) and less adsorbing (water-rinsed) filter. $0.5 \mathrm{ml}$ of a $1 \%$ glucose solution was added from the side arm to $2 \mathrm{ml}$ of mycelial suspension contained in the main compartment of the Warburg vessel; $0.2 \mathrm{ml} 20 \% \mathrm{KOH}$ was present in the centre well

\begin{tabular}{llll}
\hline $\begin{array}{l}\text { Medium for } \\
\text { suspending } \\
\text { mycelium }\end{array}$ & $\begin{array}{l}\text { Filter washed } \\
\text { in water } \\
\text { only }\end{array}$ & $\begin{array}{l}\text { Filter treated } \\
\text { with } \\
\text { detergent }\end{array}$ & $\begin{array}{l}\text { Mycelium } \\
\text { not } \\
\text { filtered }\end{array}$ \\
\hline $\begin{array}{l}\text { Filtrate (fermented } \\
\text { substrate) }\end{array}$ & 184 & $10-33$ & $158-184$ \\
\begin{tabular}{l} 
Substrate \\
\hline
\end{tabular} & 168 & 31 & - \\
\hline
\end{tabular}

mycelium and $\mathrm{h}$. If, however, the culture was filtered over the same piece of fabric previously treated with detergent and the mycelium suspended in $1 / 10$ of its culture filtrate as before, $\mathrm{QO}$ values of only 10 to 33 were obtained. This marked decrease in respiration activity when the filter was washed with detergent is likely to be due mainly to an adsorption of the mycelium on the filter, probably accompanied by a removal from the mycelium of surface-located substances. It is less likely to be due to a removal of components of the fermented substrate because in other experiments ${ }^{3}$ the influence on the respiration activity of the mycelium by its culture filtrate as compared with its original unfermented substrate was relatively small. Furthermore, when the mycelium was repeatedly washed on the filter with the original (noninoculated) sterilized substrate and suspended in the same (non-filtered) substrate, $a \mathrm{QO}_{2}$ of 168 was obtained when the filter had not been treated with detergent, compared with 31 when cleaned in detergent.

Most reports on cell-surface phenomena (transport and metabolism) in fungi and bacteria refer to processes taking place on the cytoplasmic membrane, the layer underneath the cell wall. The latter is generally regarded as an inert frame with the sole function of giving rigidity and protection to the cell. Very recently it has now been shown that the cell wall can act as a 'primary reservoir' for vitamin $B_{12}$ in a $B_{12}$-requiring Lactobacillus ${ }^{4}$. In the presently described adsorption phenomenon it would appear likely that it was also the outermost surface of the cell which was involved, thus suggesting that the organization of the metabolic processes can start in the cell wall, which used to be referred to as permeable and non-selectives.

Résumé. L'intensité de respiration d'Aspergillus oryzae est fortement diminuée par adsorption du mycélium à un filtre d'acétate de cellulose soigneusement nettoyé. Cet effet suggère que certaines substances d'une importance capitale dans le métabolisme sont éliminées de la surface des hyphes.

\section{J. Meyrath and A. F. McIntosh}

Department of Applied Microbiology and Biology. The Royal College of Science and Technology, Glasgow (Scotland), November 26, 1963.

1 J. Meyrath, Antonie van Leeuwenhoek 20, 57 (1963).

2 J. Meyrath and A. F. McIntosh, J.gen. Microbiol, 33, 47 (1963),

s J. Meyrathi and A. F. McIntosh, J. gen. Microbiol. 33 , VIII (1963).

T. Sasaki and K. Kitahara, Biochim. biophys. Acta 74, 170 (1963).

5 The authors appreciate the technical assistance provided by Mr. J. MCELROY. 